\section{A micro-level analysis of the contagion effect: Evidence from the Kurdish conflict}

\author{
Zeki Sarigil $\odot$ \\ Department of Political Science, Bilkent University
}

Journal of Peace Research

$1-15$

(C) The Author(s) 2020

Article reuse guidelines:

sagepub.com/journals-permissions DOI: $10.1177 / 0022343320957386$ journals.sagepub.com/home/jpr

(SSAGE

\begin{abstract}
The unit of analysis in almost all large-N studies on conflict contagion and diffusion is collective actors, such as states and ethnic groups or movements. Thus, contagion dynamics and processes at the individual level have been neglected. Using original data derived from a public opinion survey, this study examines the micro-level dynamics of contagion in the context of Turkey's Kurdish conflict. The study suggests that transnational ethnic ties, and in particular, cross-border familial bonds and interactions, facilitate conflict contagion through several strategic and ideational mechanisms. First, transborder familial ties and interactions amplify the demonstration effect of ethnic-kin achievements in contiguous conflict countries. Second, cross-border familial bonds facilitate collaboration between cross-border co-ethnics. Finally, such ties to conflict zones with ethnic kin groups empower pan-ethnic identities. The empirical findings show that Kurds living in Turkey who have close relatives in nearby countries hosting conflicting ethnic-kin groups (i.e. Syria, Iraq, and Iran) have stronger ethnonationalist orientations and claims against the center. However, having close relatives elsewhere (e.g. Europe) does not generate the same impact. The Kurdish case evidences that contagion processes and dynamics might vary substantially across the members of a particular ethnic group. Hence, it is necessary to broaden the conventional focus on collective actors in conflict contagion research and pay greater attention to micro-level variables and factors.
\end{abstract}

\title{
Keywords
}

conflict contagion, ethnic conflict, Kurdish conflict, transnational familial ties

Many studies in the civil conflict literature suggest that focusing on domestic factors and processes would be limited or misleading in terms of understanding the dynamics of civil conflicts and the prospects for their resolution. Instead, these studies draw attention to the border-crossing and transnational aspects and dynamics of civil conflict and suggest that many civil conflicts 'display a transnational character, where actors, resources, and events span national boundaries' (Gleditsch, 2007: 293; see also Lake \& Rothchild, 1998; Salehyan, 2007, 2009; Buhaug \& Gleditsch, 2008; Forsberg, 2008; Cederman, Girardin \& Gleditsch, 2009; Checkel, 2013; Cederman et al., 2013; Gurses, 2015; Weidmann, 2015).

Many of the studies that focus on the transnational aspects of civil conflict highlight the role of the contagion effect. In a widely cited definition, contagion refers to 'a process whereby internal conflict in one location alters the probability of another internal conflict erupting in another location at a later point in time' (Forsberg, 2014b: 144; see also Lake \& Rothchild, 1998: 3; Ayres \& Saideman, 2000: 92; Forsberg, 2014a). Thus, stressing the contagious nature of civil conflicts and wars, several studies suggest that transnational factors and linkages and interactions across state boundaries such as geographical proximity to the conflict country, as well as the presence of external bases and sanctuaries and ethnic kin groups or movements in a nearby conflict country, shape the onset, duration, nature, and outcome of civil conflicts (e.g. see Starr \& Most, 1983; Davis \& Moore, 1997; Lake \& Rothchild, 1998; Ayres \& Saideman, 2000; Saideman \& Ayres, 2000; Hegre \& Sambanis,

Corresponding author: sarigil@bilkent.edu.tr 
2006; Wolff, 2006; Salehyan \& Gleditsch, 2006; Gleditsch, 2007; Salehyan, 2007, 2009; Buhaug \& Gleditsch, 2008; Forsberg, 2008; Cederman, Girardin \& Gleditsch, 2009; Kathman, 2010; Cederman et al., 2013; Forsberg, 2014b; Gurses, 2015; Konaev \& Brathwaite, 2017; Metternich, Minhas \& Ward, 2017).

One major limitation of the literature on the transnational sources and dynamics of civil conflict, however, is that almost all of the existing large- $\mathrm{N}$ quantitative studies provide aggregate-level analyses and so focus on collective actors such as states and/ or ethnic groups and movements. As Cederman \& Gleditsch (2009) also observe, the initial large-N quantitative studies on civil conflict analyze this phenomenon at the level of the nation state and try to account for cross-national variation. However, realizing the limitations of aggregate state-centric analyses of civil conflict (e.g. the negligence of variation within states), later studies shift attention to the subnational level and focus on the conflicting groups as the unit of analysis (e.g. see Ayres \& Saideman, 2000; Saideman, 2002; Salehyan, 2007; Buhaug \& Gleditsch, 2008; Cederman, Girardin \& Gleditsch, 2009; Cederman \& Gleditsch, 2009; Cederman et al., 2013; Forsberg, 2013, 2014b; Gurses, 2015; Konaev \& Brathwaite, 2017). For example, Forsberg (2014a: 196) suggests that a better understanding of conflict diffusion requires focusing on groups rather than countries or states. Thus, several scholars implicitly or explicitly advocate a group-centric focus rather than a state-centric analysis.

Such a tendency in the relatively recent civil war literature is akin to what Brubaker (2009) calls 'groupism' or 'groupist social ontology' in ethnicity and nationalism studies. These terms refer to 'the tendency to treat various categories of people as if they were internally homogenous, externally bounded groups, even unitary collective actors with common purposes' (Brubaker, 2009: 28). Similarly, the recent contagion literature, which focuses on variance in contagion dynamics across ethnic groups, assumes that the contagion effect operates uniformly within a particular ethnic group. In brief, both state-centric and group-centric analyses of conflict contagion have provided only aggregate-level analysis and so largely overlooked the possible variance in contagion dynamics and processes within a particular ethnic group. The existing analyses, which focus on diffusion at the aggregate level, infer micro-level dynamics but do not directly test them. Hence, the existing quantitative literature is uninformative about how contagion dynamics and processes operate at the micro level (i.e. the individual level). ${ }^{1}$

Given this lacuna in the contagion literature, the current study advocates further disaggregation in civil war research and provides an individual-level analysis of the dynamics and processes of conflict diffusion in the context of Turkey's Kurdish conflict, which has been one of the most prolonged ethnic conflicts in the post-World War II era. In other words, the unit of analysis in this study is the individual members of an ethnic group rather than ethnic groups or states. A micro-level approach should enhance our comprehension of the contagion effect simply because, as Verwimp, Justino \& Brück (2009: 307) also note, 'conflict originates from individuals' behavior and their repeated interactions with their surroundings'.

The Kurdish case provides us a valuable opportunity to examine the processes of conflict contagion because Kurds are dispersed across four neighboring countries in the Middle East (i.e. Turkey, Iraq, Iran, and Syria). The majority of Kurds reside in Turkey, corresponding to around $15 \%$ to $20 \%$ of the Turkish population. In Iraq, Kurds constitute around $20 \%$ of the total population, and in Iran and Syria the Kurdish population corresponds to around $10 \%$ of the total. Thus, Kurds constitute a multistate ethnic group. Additionally, each of these contiguous states has been struggling with challenges regarding their respective Kurdish ethnonationalist groups and movements. Hence, in terms of conflict contagion or diffusion, the Kurdish conflict constitutes one of the most likely cases. Surprisingly, however, we have little quantitative research on the dynamics and mechanisms of contagion in the context of the Kurdish ethnic conflict (for an exception, see Gurses, 2015).

The following research questions direct the current study. To what extent and how do transnational factors, such as border-transgressing familial ties and interactions, shape ethnonationalist orientations and claims against the center? Are those who have close relatives in nearby conflict countries more ethnonationalist than others? To ask this differently, do strong transnational linkages to and interactions with contiguous conflict countries with ethnic kin empower ethnic group members' ethnonationalist orientations and demands? If so, why?

Building on the previous literature on the role of transnational linkages in ethnic conflict contagion, this

\footnotetext{
${ }^{1}$ For a similar criticism of research on violent civil conflict, see Verwimp, Justino \& Brück (2009).
} 
study first suggests that transnational ethnic linkages involve not only kinship ties but also familial ties and interactions. This study expects cross-border familial bonds and interactions to facilitate the demonstration effect of ethnic kin achievements in nearby conflict countries and also facilitate transnational collaboration among transborder co-ethnics, thus shaping ethnic group members' ethnonationalist tendencies and demands. One might also expect cross-border familial ties and interactions to empower pan-ethnic identities and so boost peaceful and/or violent ethnic mobilization. Statistical analyses based on original public opinion survey data provide empirical support for such hypothetical expectations. The empirical findings suggest that having close relatives in neighboring conflict countries where ethnic-kin groups are granted several concessions positively influences the ethnonationalist orientations and demands of ethnic group members in the home country. However, transnational familial ties to non-contiguous and non-conflict countries do not generate such an impact.

The rest of the article is organized as follows. The theoretical section (next) first discusses the role of transnational ethnic ties in conflict contagion and then presents hypotheses. The subsequent section explores transnational ethnic linkages within the context of the Kurdish conflict in Turkey. The data and methods section presents the survey data, variables of interest, and the measurements. The results section presents the multivariate analyses. The final section summarizes the main findings and discusses the broader implications of the Kurdish case.

\section{Transnational ethnic linkages and conflict contagion}

Several studies acknowledge that transnational ethnic ties or linkages and networks are likely to play a substantial role in the processes and dynamics of conflict contagion or diffusion (e.g. see Ayres \& Saideman, 2000; Salehyan \& Gleditsch, 2006; Buhaug \& Gleditsch, 2008; Forsberg, 2008, 2013, 2014a,b; Cederman, Girardin \& Gleditsch, 2009; Gurses, 2015). The literature identifies several strategic and ideational mechanisms through which transnational ethnic ties are likely to shape ethnic demands and mobilization. One key mechanism is strategic learning and emulation. Members of disadvantaged ethnic groups may learn from the achievements and victories of ethnic-kin groups or movements in neighboring conflict countries and imitate those ethnic groups or movements (Horowitz, 1985; Hill \& Rothchild, 1986; Kuran, 1998; Lake \& Rothchild, 1998; Forsberg, 2008, 2014a; Metternich, Minhas \& Ward, 2017; Weidmann, 2015). Transnational ties and interactions facilitate strategic learning and inspiration by helping access information about new tactics or strategies, organizational skills, ethnonationalist ideas, and clues and discourses that ethnic group members can utilize in their struggles and negotiations with their own state.

One specific form of strategic learning and emulation is called the demonstration effect, which refers to 'a process where political action by one group stimulates other groups to promote their own cause' (Forsberg, 2013: 330). The demonstration effect might trigger other groups' action(s) by altering their risk assessments and/ or by serving as a strategic guide or blueprint in their relations with their own state. Using the words of Lake \& Rothchild (1998: 26),

ethnic conflict in one country may prompt groups in another to make more extreme demands. Groups in one state, witnessing ethnic mobilization or, more importantly, political success by ethnic groups in another, may increase their own political agitation and demand a significantly greater share of the resource pie - increasing the probability of conflict [...] Similarly, ethnic conflict elsewhere may cause groups to update their beliefs about the likely demands of other groups in their own country [....] Finally ethnic conflict abroad may lead groups to update their beliefs about the costs of protest, or, ultimately violence and their probability of success. Effective protest or violence abroad may lead groups at home to believe that they too may be able to obtain valued ends through coercion.

Forsberg (2008) also draws attention to the demonstration effect by arguing that transnational kinship bonds or links create a favorable environment for ethnic inspiration and so ethnic mobilization. In brief, ethnonationalist activism and mobilization by kindred groups in a nearby conflict country and accommodating an ethnic-kin group's demands in that country would encourage ethnic group members to increase their own demands from the home state.

Another major mechanism of conflict diffusion is collaboration between cross-border co-ethnics. As Gleditsch suggests, 'ethnic kin and émigré communities in other states have often played an important role in mobilizing and financing insurgencies [....] Groups that have transnational communities should have a generally larger pool of resources that they can draw upon in mobilizing for violent conflict' (2007: 297-298; see also Davis \& Moore, 1997; Saideman, 2002; Gurses, 2015; Konaev $\&$ Brathwaite, 2017). Thus, other than serving as a model to be followed and emulated, ethnic-kin groups 
in nearby countries might also provide direct material support (e.g. resources such as recruits or fighters, weapons, communication, know-how, organizational skills, and finance) for ethnonationalist groups and insurgencies. Since resource mobilization is crucial for ethnopolitical movements (see also Adamson, 2013; Bakke, 2013), direct material support from ethnic-kin groups in nearby countries might substantially contribute to the conflicting ethnic group's ability to effectively mobilize and challenge the state.

Last but not least, transnational ethnic ties and interactions might also operate at a relatively more ideational level and directly or indirectly shape ethnonationalist orientations and mobilization. Transnational ethnic linkages might substantially shape ethnic group members' attachments, emotions, and attitudes towards co-ethnics within and across national borders and towards states hosting ethnic-kin groups. For instance, the oppression and suffering of ethnic-kin groups during an ethnic conflict in a nearby country would activate transnational ethnic ties or bonds. The increasing salience of transborder ties among ethnic co-brethren would in return empower pan-ethnic identities, consciousness, feelings, and solidarities. Such transnational ideational processes are likely to trigger or facilitate ethnic mobilization and boost ethnic demands against the center.

One telling example of the role of pan-ethnic identities, emotions, and solidarities in ethnic mobilization is the Kobane protests that took place in Turkey in October 2014. When the Islamic State of Iraq and Syria (ISIS, a.k.a. ISIL, IS or Daesh) initiated an armed attack to capture the Kurdish-held border town of Kobane in northern Syria in September 2014, it sparked largescale pro-Kobane protests by Turkey's Kurds in provinces such as Diyarbakır, Van, Gaziantep, Mardin, Mersin, İzmir, Ankara, and İstanbul. Kurdish protestors demanded that the Turkish government open a corridor to the besieged border town of Kobane for humanitarian and military aid. The demonstrations suddenly turned into violent clashes between Kurdish protesters and Turkish security forces and led to around 50 deaths. Many young Turkish Kurds also crossed national borders and joined the Syrian Kurdish forces in Kobane to defend the town against the ISIS attacks (Lawson, 2016). The case of Turkish Kurds' support for the battle of Kobane (September 2014-March 2015) in northern Syria suggests that transnational ethnic ties or linkages might trigger or escalate ethnic mobilization and conflict through relatively more ideational mechanisms such as transnational pan-ethnic identities, sentiments, and solidarities (see also Gourlay, 2017).
This study expects these three distinct mechanisms (i.e. strategic learning and emulation, cross-border cooperation among ethnic-kin groups, and transnational panethnic identities and feelings) to be relatively stronger among those ethnic group members who have close relatives in a nearby conflict country hosting ethnic-kin groups. As Lake \& Rothchild (1998: 4) note, ethnic conflict diffusion 'occurs largely through information flows that condition the beliefs of ethnic groups in other societies'. Similarly, Weidmann (2015) claims that transnational information linkages and flows, such as peer-topeer communication, play a major role in conflict diffusion. In her analysis of the role of transnational insurgents in civil war, Bakke (2013: 35) also draws attention to 'the transfer of information or resources through personal networks and social bonds'. Since transnational familial bonds and networks would facilitate cross-border interactions and peer-to-peer communication and so experience sharing and information flows, we should expect strategic learning and emulation, the demonstration effect, material flows, and pan-ethnic identities and sentiments to be relatively stronger among those who have close relatives in a nearby country where ethnic-kin groups have achieved major political, economic, and/or territorial gains vis-à-vis their own states. In sum, the three distinct mechanisms presented above have the same observable implication: stronger ethnic consciousness and demands among those who have transnational familial ties to contiguous conflict countries with ethnic kin. Thus, one might expect that

Hypothesis 1: The members of an ethnic group with close relatives in contiguous conflict countries where warring ethnic-kin groups have achieved major gains against their own state would have relatively stronger ethnonationalist orientations and demands.

An evident corollary to this hypothesis is that having close relatives in non-contiguous countries without conflicting ethnic-kin groups should not generate the same impact on ethnic group members' ethnonationalist orientations and claims against the center. Hence, another hypothesis to be tested is as follows:

Hypothesis 2: Having close relatives in non-contiguous and non-conflict countries would not empower ethnonationalist orientations and demands.

\section{Turkish Kurds' transnational linkages}

Due to historical, political, and economic conditions and factors, many Turkish Kurds have close relatives living in 
neighboring as well as in European countries. In other words, Turkey's Kurds have had strong transnational bonds, networks, and relations in the region and in Europe.

\section{Ties to nearby countries}

The survey results indicate that around $23 \%$ of respondents have close relatives in nearby countries (i.e. Iraq, Iran, and Syria). Regarding the specific reasons for Turkish Kurds' strong linkages to nearby countries, we should take into account factors such as the modern state formation, mass migration and insurgent recruitment.

The modern state formation. Kurds are known as one of the autochthon peoples of the Middle East. However, when the borders of the modern states were formed after World War I, the traditional Kurdish homeland was divided among Turkey, Syria, Iraq, and Iran (McDowall, 2004). In other words, the modern state borders in the region do not correspond to the boundaries of the Kurdish ethnic group. As a result, Kurds constitute an ethnic minority in those countries, where the majority consists of Arabs, Persians, or Turks. This means that many Kurdish tribes and families have members in neighboring countries. This is also valid for Turkey's Kurdish ethnic minority; as indicated above, around one quarter of Turkey's Kurds have close relatives across national borders in Syria, Iraq, and Iran. As a result, it has been a tradition among thousands of Turkish Kurds living in border towns and villages to cross the border during religious holidays and celebrate with their relatives in neighboring countries. Beyond strong cross-border social connections, networks and interactions (cross-border marriages, visits, etc.), Kurdish relatives residing in border towns and villages in Turkey and in nearby countries have also strong economic networks and relations such as cross-border trade (legal and illegal).

Mass migration. Due to various motivations such as security, education, and jobs, thousands of Turkish Kurds have also migrated to nearby countries. For instance, in the 1920s and 1930s, the young Turkish Republic was challenged by several Kurdish revolts in the east and southeast (e.g. the Sheikh Said Revolt, 1925, the Ağr1 Revolt, 1926-30, and the Dersim Revolt, 1936-38). The state responded to those revolts with rather repressive measures. To escape state repression, many Kurds resettled in Syria (van Bruinessen, 2000). Another wave of migration to nearby countries took place in the 1990s, when the armed conflict between Turkish security forces and the Kurdistan Workers' Party (Partiya Karkarén Kurdistané, PKK) intensified.
Throughout the 1990s, as a security measure in its fight against the PKK, the state evacuated around 3,500 settlements (villages and districts) in eastern and southeastern Turkey. This led to the displacement of more than one million Kurds (Belge, 2016). Many migrated to Turkey's major western and central cities, such as Istanbul, Ankara, and Izmir, while others ended up in neighboring countries. As a result, several Kurdish refugee camps were formed in northern Iraq and northern Syria.

Better social and economic conditions and opportunities were other major motivations behind the Kurdish outflow to neighboring countries. Beginning in the early 1990s, especially northern Iraq became an attractive destination for many young Turkish Kurds due to the major economic, political, and territorial gains that Iraqi Kurds were achieving from the central Iraqi state (see below). Since then an increasing number of Turkish Kurds have moved to northern Iraq either for education reasons or for jobs in various sectors such as service, construction, and energy (see also Marcus, 2007: 301-302).

Insurgent recruitment. Finally, the PKK, which has been waging an armed struggle against the Turkish state since the mid-1980s, has thousands of active members in northern Syria and Iraq. As Salehyan (2007) observes, one of the most common strategies of insurgents or terrorists is the use of external sanctuaries, which enables them to avoid a state's judicial and military repression, lowers the costs of armed struggle, and enhances rebel groups' bargaining power vis-à-vis their home state. These practices apply to the PKK as well, which, since the early 1980s, has been using several bases in nearby countries as safe havens in its armed conflicts with the Turkish state. The PKK's headquarters are in the Qandil Mountains in northern Iraq, and it has several camps in other mountainous areas close to Turkish borders. As a result, thousands of Turkish Kurds residing in nearby countries are active members of the PKK. In addition, due to fear of arrest, many former PKK members have not returned to Turkey and have settled in Iraqi Kurdish cities (Marcus, 2007). Finally, since the Syrian civil war erupted in 2011, many young Kurds living in Turkey have crossed national borders and joined the Kurdish movement in northern Syria to fight against radical jihadists and/or Syrian regime forces.

In brief, due to historical reasons (i.e. the divisive modern state borders) and population movements (i.e. civilian migration and cross-border movement of militants), substantial numbers of Turkish Kurds have been living in nearby countries, especially in Iraq and Syria. In the end, all these factors have tightened Turkish Kurds' 
familial ties to neighboring countries, which host conflicting ethnic kin.

\section{Ties to European countries}

Turkey's Kurds also have strong family ties and linkages to western European countries. For instance, 33\% of survey respondents declared that they have relatives residing in European countries. In the 1960s, many booming western European economies experienced labor shortages and thus many Turks and Kurds migrated to those countries in the 1960s and 1970s as guest workers, particularly to Germany. Another wave of Kurdish exile to Europe took place in the post-1980 period. During Turkey's military regime (1980-83), state pressure on Kurdish ethnonationalist activists, writers, journalists, politicians, and intellectuals increased. As a result, many of them sought political asylum in western European countries (van Bruinessen, 1998; EccariusKelly, 2002; Adamson, 2013; Gourlay, 2017). In addition, when the intensity of armed conflict between Turkish security forces and the PKK increased in the eastern and southeastern parts of Turkey in the 1990s, many Kurds sought refuge from military pressure in Europe as well (van Bruinessen, 2000). In brief, Turkish Kurdish labor migrants, family reunification, and political refugees formed a sizable Kurdish diaspora in countries such as Germany, France, the Netherlands, Switzerland, Belgium, and Sweden. As of the early 2000s, the number of Turkish Kurds in Europe was estimated at around 600,000 (van Bruinessen, 2000).

In line with the conflict contagion theory presented above, the current study expects that transnational ties to non-contiguous and non-conflict European countries should not boost Turkish Kurds' ethnonationalist orientations and demands. Instead, this study anticipates that having transnational linkages to nearby conflict countries where ethnic-kin groups have achieved major social, economic, and political gains should have a positive impact on Turkish Kurds' ethnonationalist orientations and demands. These results are expected simply because familial ties to neighboring countries would strengthen the demonstration and spillover effects of ethnic-kin empowerment in nearby countries. Indeed, in the last decades, Turkish Kurds' brethren across national borders, especially Iraqi and Syrian Kurds, have achieved major political, economic, and territorial gains (de facto and/or de jure).

To briefly present Kurdish empowerment in Iraq, in the aftermath of the Gulf War (1990-91), US-led coalition forces set up a no-fly zone and a safe haven in northern Iraq (north of the 36th parallel) to defend Iraqi Kurds against Saddam Hussein's forces. This led to the rise of de facto Kurdish autonomy in northern Iraq in the early 1990s. The 2003 US-led invasion of Iraq further enhanced the status of Iraqi Kurds. This invasion, which ousted Saddam Hussein's Ba'athist regime from power, resulted in a new constitution in 2005. Based on the principle of federalism, the constitution set up the official, semi-autonomous Kurdish Regional Government (KRG) in northern Iraq. The establishment of the KRG - which has its own parliament, elected president, anthem, and flag, as well as a military force known as peshmerga - meant the official recognition of Kurdish self-rule in northern Iraq.

With respect to Kurdish accomplishments in Syria, after decades-long state discrimination and repression, Syrian Kurds have also achieved major gains. For instance, after the civil war began in 2011, the Syrian state extended citizenship status to stateless Kurds (around 400,000 people) and expanded their property rights to dissuade Kurds from joining the mostly SunniArab revolts against the regime. A much more significant development occurred after the Syrian army evacuated most Kurdish areas in 2012. At this time, the Democratic Union Party (Partiya Yekitiya Demokrat, PYD) and its military wing, the People's Protection Units (Yekîneyên Parastina Gel, YPG) took control of several parts of northern and northeastern Syria in July of that year (Lowe, 2014; Romano \& Gurses, 2014; Kaya \& Whiting, 2017; Oktav, Parlar Dal \& Kursun, 2018).

In brief, Kurds in Iraq and Syria have achieved unprecedented gains in the last decades (i.e. de jure Kurdish regional autonomy and government in northern Iraq since 2005 and de facto Kurdish autonomy in northern Syria since 2012). Regardless of whether Kurds will be able to maintain these economic, political, and territorial concessions in the future, this study expects that Kurdish empowerment in nearby countries should have some impact on Turkish Kurds' ethnic demands and mobilization. As noted above, the study hypothesizes that Turkish Kurds who have strong transnational ties to and interactions with neighboring conflict countries are more likely to be inspired and encouraged by Kurdish empowerment in those countries and so increase their own ethnic demands from the Turkish state. One might also expect cross-border cooperation and transnational panethnic identities and solidarities to be stronger among such Kurds.

Having said that, an alternative explanation might assert that the differential impact of having relatives in contiguous conflict countries with ethnic kin and having 
relatives in non-contiguous and non-conflict European countries on Kurds' ethnonationalist tendencies and demands might be due to a self-selection bias. For example, it might be the case that unlike neighboring countries, European countries might have received Turkish Kurds with lower ethnic consciousness and ethnonationalist orientations. However, studies on Kurdish diaspora confirm the presence of high levels of ethnopolitical awareness and activism among Kurdish migrants in Europe (e.g. see van Bruinessen, 1998, 2000; EccariusKelly, 2002; Marcus, 2007; Adamson, 2013; Baser, 2017; Gourlay, 2017). First of all, as discussed above, especially in the post-1980 period, facing increasing state pressure and repression, many Kurdish activists (e.g. intellectuals, writers, journalists, and politicians, as well as the victims of torture and relatives of PKK members and of those who were subject to extra-judicial killings) have sought political asylum in European countries. In other words, several European countries have provided safe havens for Kurdish political migrants. Thus, the Kurdish exile to Europe suggests that politically active Kurds have migrated to Europe as well. Moreover, taking advantage of the relatively more liberal political environment in several European countries, the PKK-led Kurdish ethnopolitical movement has been highly organized and active within the Kurdish diaspora in Europe. Kurdish migrants in Europe have provided substantial financial and human resources to the PKK and so the PKK has had thousands of active members and sympathizers in several European countries. The existing research on Kurdish diaspora further shows that Kurdish migrants in Europe have also been involved in various forms of ethnopolitical activism and mobilization, such as lobbying host states to advance the Kurdish cause; organizing mass protests and demonstrations, sit-ins, highway blockades, hunger strikes, campaigns, petitions, and commemoration ceremonies; and establishing proKurdish foundations, associations, cultural centers, and media. As another indicator of strong ethnopolitical consciousness and activism among Turkish Kurds residing in Europe, during Turkish general elections, proKurdish political parties in Turkey usually receive substantial support from Kurdish migrants in Europe.

The following section presents the data, measurement of key variables, and statistical analyses and empirical findings.

\section{Data and methods}

\section{Survey data}

This study utilizes original data provided by a nationally representative public opinion survey of adult respondents, conducted in Turkey in April 2013. The survey, which was designed by a research team including the author of this article, aimed at collecting original and comprehensive data on Kurds' ethnic demands and orientations. Trained and experienced interviewers of a private public-opinion research company based in Istanbul conducted the survey through face-to-face interviews with participants from 50 (out of 81) Turkish provinces, 174 districts (ilçe), and 398 neighborhoods (mahalle) and villages. ${ }^{2}$ Regarding sampling, first a multistage, stratified, cluster-sampling procedure was followed to identify households. Then, age and gender quotas were used to select one individual from each household. Since this study focuses on the ethnonationalist tendencies of Kurdish ethnic group members, the empirical analyses below were conducted by utilizing the data provided by the Kurdish subsample (1,237 participants, corresponding to around $17.4 \%$ of the total sample).

\section{Dependent variable}

As this study investigates the effect of ethnic group members' transnational ties on their ethnonationalist orientations and demands, ethnonationalist tendencies constitute the dependent variable in the statistical analyses. Ethnonationalism simply stands for a political movement or a form of identity politics by an ethnic group (e.g. see Rothschild, 1981; Lecours, 2000; Romano, 2006; Wolff, 2006; Eriksen, 2010). For instance, Rothschild (1981: 6) notes that ethnonationalism is 'the transformation of ethnicity from a purely personal quest for meaning and belonging into a group demand for respect and power'. An ethnic group or movement might raise various modest or radical claims and demands against the center, ranging from the legal recognition of distinct ethnic identities to several cultural and political rights such as linguistic rights and power-sharing arrangements (e.g. regional autonomy). A much more extreme demand would be secession, which refers to 'a kind of collective action, whereby a group (whether officially recognized as a legitimate political subunit or not) attempts to become independent from the state that presently claims jurisdiction over it and, in doing so, seeks to remove part of the territory from the existing state' (Buchanan, 1991: 75). Thus, unlike ethnocultural and ethnopolitical demands

\footnotetext{
${ }^{2}$ Taking potential social desirability bias into account, the survey was conducted at the beginning of the Peace Process (2013-15), which brought a relatively more liberal political environment. Also, Kurdish speaking interviewers conducted the survey in Kurdish-majority provinces.
} 
on the home state, ethnic separatism involves the rejection of the sovereignty and jurisdiction of the home state, political disintegration, and territorial dismemberment (Griffiths, 2016; Roeder, 2018).

Advancing such ethnic claims and demands against the center should be understood as a form of ethnic mobilization (Jenne, Saideman \& Lowe, 2007). As several studies suggest, having ethnonationalist attitudes and claims also increases the likelihood of further peaceful and/or violent ethnic mobilization, such as ethnic voting, ethnic protests, and ethnic rebellion or war (e.g. see Jenne, Saideman \& Lowe, 2007; Cederman, Wimmer \& Min, 2010; Harff \& Gurr, 2018). This observation is also valid for the Kurdish case: Kurds with strong ethnonationalist attitudes and tendencies are more likely to support pro-Kurdish political parties and the violent PKK (e.g. see Sarigil \& Karakoc, 2016).

To measure ethnonationalist orientations, the survey questionnaire included items about respondents' support for Kurds' various moderate and extreme demands, such as education in the Kurdish language, place names in Kurdish, Kurdish sermons, elective Kurdish courses at public schools, public services in Kurdish, the recognition of Kurdish as an official language, a regional flag, regional assembly, regional autonomy, and secession. To determine whether those items could be reduced to a small number of underlying components, I conducted factor analyses, which generated two different factors (see Online appendix A for the results). Items related to relatively more sensitive and extreme demands, such as power-sharing arrangements (i.e. demands for a regional flag, regional parliament, and autonomy) and secession, had relatively higher factor loadings on the first component, and so this grouping was labeled as 'segregationist ethnonationalism'. 3 Then, adding those items together, an additive index of segregationist ethnonationalism was constructed. ${ }^{4}$ Thus, the dependent variable Segregationist ethnonationalism is an ordinal variable, ranging from 0 to 6. High values represent stronger ethnonationalist orientations.

Items related to relatively more modest cultural and linguistic demands (i.e. elective Kurdish courses, place names in Kurdish, Kurdish sermons, and public service in Kurdish) load highly on the second component, which was labeled integrationist

\footnotetext{
${ }^{3}$ I am grateful to one of the reviewers for drawing my attention to such a conceptualization.

${ }^{4}$ The alpha reliability test suggests high internal consistency $(\alpha=$ $0.87)$.
}

ethnonationalism'. 5 Those items were combined to construct an additive index, capturing more moderate and integrationist aspects of ethnonationalism. The dependent variable Integrationist ethnonationalism is also an ordinal variable, ranging from 0 to 4 (high values mark stronger ethnonationalist orientations).

\section{Independent variables}

In this study, transnational ethnic ties and interactions constitute the main independent variable. In the existing quantitative studies on conflict contagion, having ethnic kin in a nearby country is frequently used as an indicator of an ethnic group's transnational bonds and interactions. However, at the individual level, cross-border ethnic kin would not be a variable, simply because the presence or absence of an ethnic-kin group in a contiguous state would be the same for all the members of a particular ethnic group. For instance, as presented above, all Turkish Kurds have ethnic-kin groups in neighboring countries. Thus, how can we measure transnational linkages and interactions at the individual level? Since ethnic group members differ in terms of having family members or close relatives in contiguous or noncontiguous countries, this study utilizes transnational familial ties to capture individuals' transnational linkages and interactions. The variable Cross-border relative measures whether a respondent has a close relative in neighboring conflict countries (i.e. Syria, Iraq, and/or Iran). If the respondent does not have relatives across national borders, this variable is coded 0 (no); otherwise it is coded 1 (yes). The variable European relatives captures whether the respondent has close relatives residing in a European country (i.e. non-contiguous and non-conflict countries). Similarly, it is a binary variable, coded as 0 (no) or 1 (yes).

\section{Control variables}

The existing studies on ethnic mobilization and conflict suggest that several other variables might affect ethnic group members' ethnonationalist orientations and demands. Thus, in order to control for the impact of potentially confounding variables and factors, several control variables have been included into the multivariate models. First, several previous studies have found that experiencing and/or perceiving state discrimination (Discrimination perception) and/or exclusion in social, political, and economic realms might promote ethnic group

\footnotetext{
${ }^{5}$ The alpha reliability test suggests a fair degree of internal consistency $(\alpha=0.69)$.
} 
members' resentment towards their home state and so facilitate mobilization along ethnic lines (e.g. see Horowitz, 1985; Gurr, 1994; Ayres \& Saideman, 2000; Regan \& Norton, 2005; Jenne, Saideman \& Lowe, 2007; Cederman, Wimmer \& Min, 2010; Cederman, Gleditsch \& Buhaug, 2013; Sarigil \& Fazlioglu, 2014; Gleditsch \& Polo, 2016; Sarigil \& Karakoc, 2016). In other words, discrimination (economic and/or political) is likely to promote ethnonationalist orientations and demands.

Second, Socio-economic status (e.g. income and education levels) might also matter in terms of ethnic mobilization. Similar to discrimination perception, low socio-economic status and/or economic dissatisfaction might also activate discontent and grievances and so frustrations, which in turn can motivate peaceful and/or violent ethnic mobilization (Gurr, 1970).

Another potential predictor of ethnonationalism is Region. Existing research on ethnic mobilization and conflict shows that geographical concentration matters (e.g. see Ayres \& Saideman, 2000; Toft, 2003; Jenne, Saideman \& Lowe, 2007). Ideationally, one might expect that ethnic group members living in areas inhabited mostly by co-ethnics (i.e. ethnic homeland) would have a stronger ethnic consciousness and attachments and so be more receptive to ethnonationalist ideas and mobilization. Strategically, territorial concentration increases the likelihood of more radical ethnic claims and demands against the center for several reasons. First, territorial concentration facilitates political, social, and economic self-sufficiency, which enhances the credibility of more extreme demands against the central government (e.g. autonomy or secession) (Jenne, Saideman \& Lowe, 2007). Second, ethnic homogeneity helps ethnic group members better justify their claims for regional autonomy, regional parliament, or secession (Toft, 2003). Hence, we might expect that Kurds living in Turkey's eastern and southeastern areas (which, indeed, are mostly inhabited by Kurds) would have stronger ethnonationalist tendencies and claims.

Another regional factor that we should take into account is the possible impact of residing in a province, sharing a border with a neighboring country that hosts warring ethnic-kin groups (i.e. Syria, Iraq, and Iran). One might expect cross-border interactions (material and/or ideational) with ethnic-kin groups in neighboring countries to be denser among those Kurds who live or reside in Turkey's border provinces. This might in turn empower their ethnic awareness and claims against the center. Thus, to capture the possible impact of geographical proximity to countries with warring ethnic kin, I created a binary variable, Border province, which is coded as follows: 0 (not living in a border province); 1 (living in a border province).

Since some studies suggest that religion-related factors (i.e. Religiosity and Religious sect) are likely to play a role in Kurdish ethnonationalist orientations (e.g. Sarigil \& Karakoc, 2016), the models also control for the possible impact of those factors. Regarding the measurement of religiosity, the questionnaire included several items about various dimensions of religiosity such as belief, practice, and attitude. Since almost all participants expressed their belief in Allah and the afterlife, those items were excluded from the analyses. Factor analyses with the remaining religion-related items generated one factor that I labeled as Attitudelpractice (see Online appendix B for the results). Utilizing those items, I constructed a religiosity index. It is also an ordinal variable, ranging from 0 to 6 (high values designate stronger religiosity). Other control variables include Ideology (a leftright division), Age, and Gender. For descriptive statistics of all the variables, see Table I.

\section{Results}

Table II presents the multivariate analyses of the effect of transnational familial ties on Turkish Kurds' ethnonationalist tendencies. Since the dependent variables are categorical and ordinal, the models are estimated using ordinal logit regression. Beginning with the baseline models (Models 1a and 2a), which include only the control variables, the results indicate that discrimination empowers ethnonationalist orientations, supporting the grievance hypothesis. This finding contradicts Ayres \& Saideman's (2000) study, which suggests that political and economic discrimination may actually discourage radical ethnic demands such as separatism. The findings of the current study, however, indicate that discrimination may not necessarily pay off.

Ideological orientations matter as well. Compared to right-oriented Kurds, left-oriented Kurds are relatively more ethnonationalist, because the latter are relatively more receptive to the ethnonationalist ideas and discourses promoted by the Kurdish movement in Turkey, which is rooted in the leftist movement. Interestingly, religious factors also affect Kurds' ethnonationalist tendencies, where moving from a low to high level of religiosity increases ethnonationalism. Also, ethnonationalist orientations are stronger among Shafi Kurds. These empirical findings challenge the Muslim brotherhood argument, which has been advocated by the Turkish state and Islamic circles. Assuming a mutually exclusive 
Table I. Descriptive statistics of variables

\begin{tabular}{|c|c|c|c|c|c|}
\hline Variables & $N$ & Mean & Std dev. & Min. & Max. \\
\hline \multicolumn{6}{|l|}{ Dependent } \\
\hline Segregationist ethnonationalism (index) & 1,180 & 3.66 & 2.190 & 0 & 6 \\
\hline Integrationist ethnonationalism (index) & 1,220 & 3.46 & 0.979 & 0 & 4 \\
\hline \multicolumn{6}{|l|}{ Independent } \\
\hline Cross-border relatives & 1,205 & 0.23 & 0.420 & 0 & 1 \\
\hline European relatives & 1,228 & 0.33 & 0.471 & 0 & 1 \\
\hline \multicolumn{6}{|l|}{ Control } \\
\hline Discrimination perception & 1,218 & 0.54 & 0.499 & 0 & 1 \\
\hline Ideology (left-right) & 1,195 & 2.77 & 0.799 & 1 & 5 \\
\hline Religiosity index (attitude/practice) & 1,194 & 4.27 & 1.783 & 0 & 6 \\
\hline Religious sect (Shafi) & 1,206 & 0.60 & 0.490 & 0 & 1 \\
\hline Gender (female-male) & 1,235 & 1.53 & 0.499 & 1 & 2 \\
\hline Age & 1,237 & 37.64 & 13.427 & 18 & 83 \\
\hline Education & 1,237 & 3.52 & 1.571 & 1 & 7 \\
\hline Household income group & 1,164 & 1.73 & 1.119 & 1 & 10 \\
\hline Economic satisfaction & 1,231 & 1.71 & 0.629 & 1 & 3 \\
\hline Region (east and southeast) & 1,237 & 0.49 & 0.500 & 0 & 1 \\
\hline Border province & 1,237 & 0.18 & 0.383 & 0 & 1 \\
\hline Rural-urban & 1,237 & 2.05 & 0.814 & 1 & 3 \\
\hline
\end{tabular}

relationship between Islamic loyalties and attachments and ethnic particularities and identities, this approach expects that ethnic consciousness and identities and so ethnonationalist aptitudes and claims would be weak among religious Kurds. The empirical results of this study contradict the Muslim brotherhood argument or hypothesis (see also Sarigil \& Fazlioglu, 2014; Gurses \& Rost, 2017).

Another notable finding is that regional factors do matter in terms of ethnonationalism orientations and claims. For instance, Kurds residing in Turkey's eastern and southeastern regions (mostly inhabited by Kurds) are relatively more ethnonationalist. This finding confirms that geographical concentration of an ethnic group provides a favorable ground for ethnonationalism. Furthermore, living in a border province does not affect integrationist ethnonationalism but empowers segregationist ethnonationalism. In other words, proximity to a conflict zone with warring ethnic kin seems to boost extreme ethnic claims against the center. This finding supports the conflict contagion hypothesis.

Interestingly, socio-economic factors do not perform well in terms of predicting Kurds' ethnonationalist orientations. Such factors either do not matter or have contrasting impact. Practically speaking, this finding implies that improvements in Kurds' socio-economic status (e.g. increasing education and income levels) may not necessarily contain their ethnonationalist orientations.
Adding the key variables of interest (i.e. crossborder relatives and European relatives) to the baseline models lowers the AIC scores, which suggests that the quality of the models improves. As expected, having relatives across national borders has a positive and statistically significant impact on segregationist and integrationist ethnonationalist orientations alike, and this relationship holds across various model specifications (see Models 1c, 1d, 2c, and 2d). Thus, compared to Kurds who do not have familial connections to nearby conflict countries, those who do have crossborder connections and interactions have stronger ethnonationalist orientations and demands. This finding suggests that Kurds with familial connections to nearby countries that have conflicting ethnic-kin groups are relatively more likely to become involved in ethnic mobilization.

To get a better sense of the substantive impact of having a cross-border relative on ethnonationalist orientations, the study also calculates the predicted probabilities of segregationist and integrationist ethnonationalism (based on Models 1d and 2d). Figure 1 presents the cumulative predicted probabilities, and the results indicate that having a close relative in a nearby conflict country increases the predicted probability of being in the higher categories of segregationist and integrationist ethnonationalism. For instance, having a cross-border relative increases the probability of being in the highest category of segregationist ethnonationalism (Category 6) by $12.3 \%$ and 


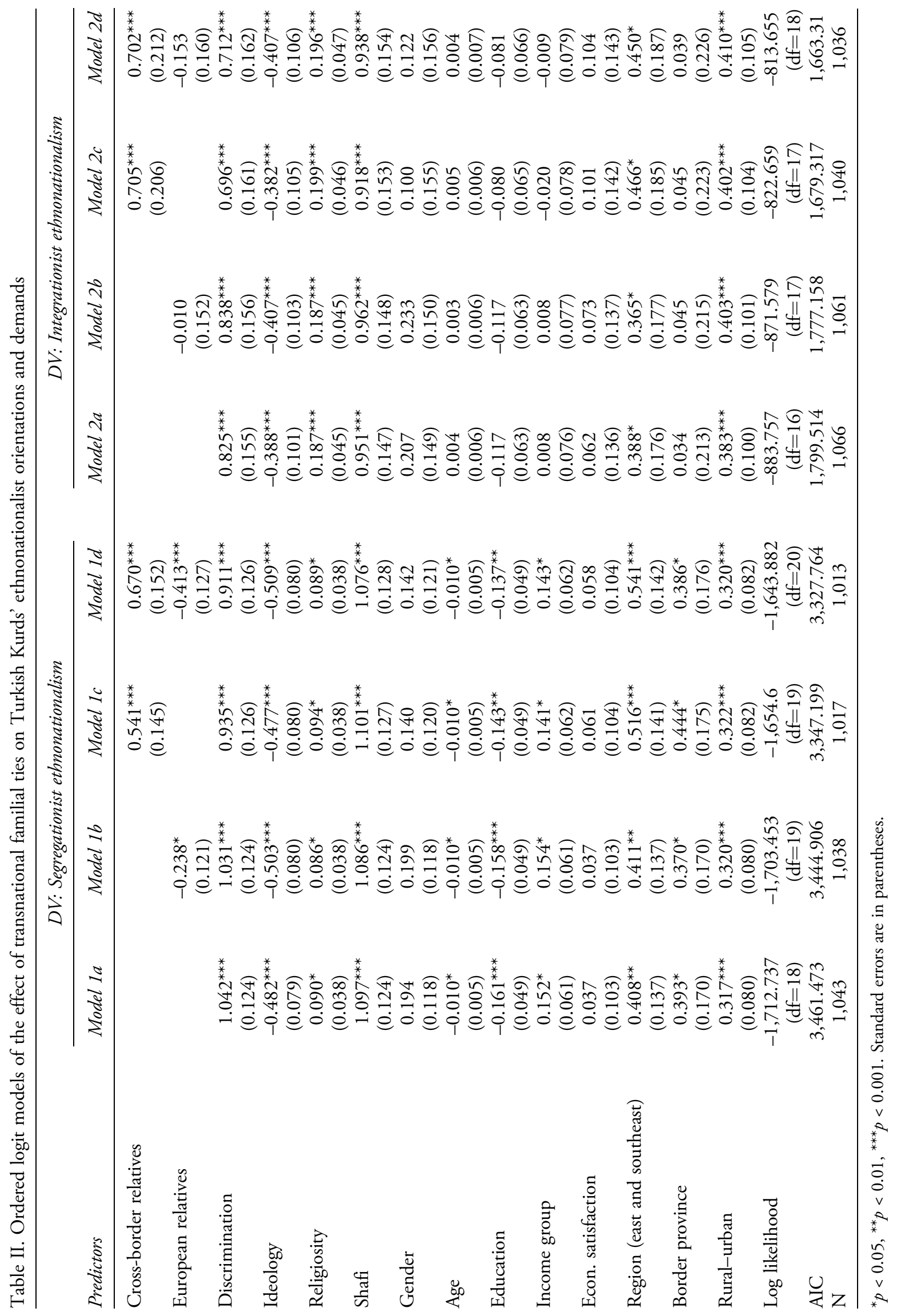



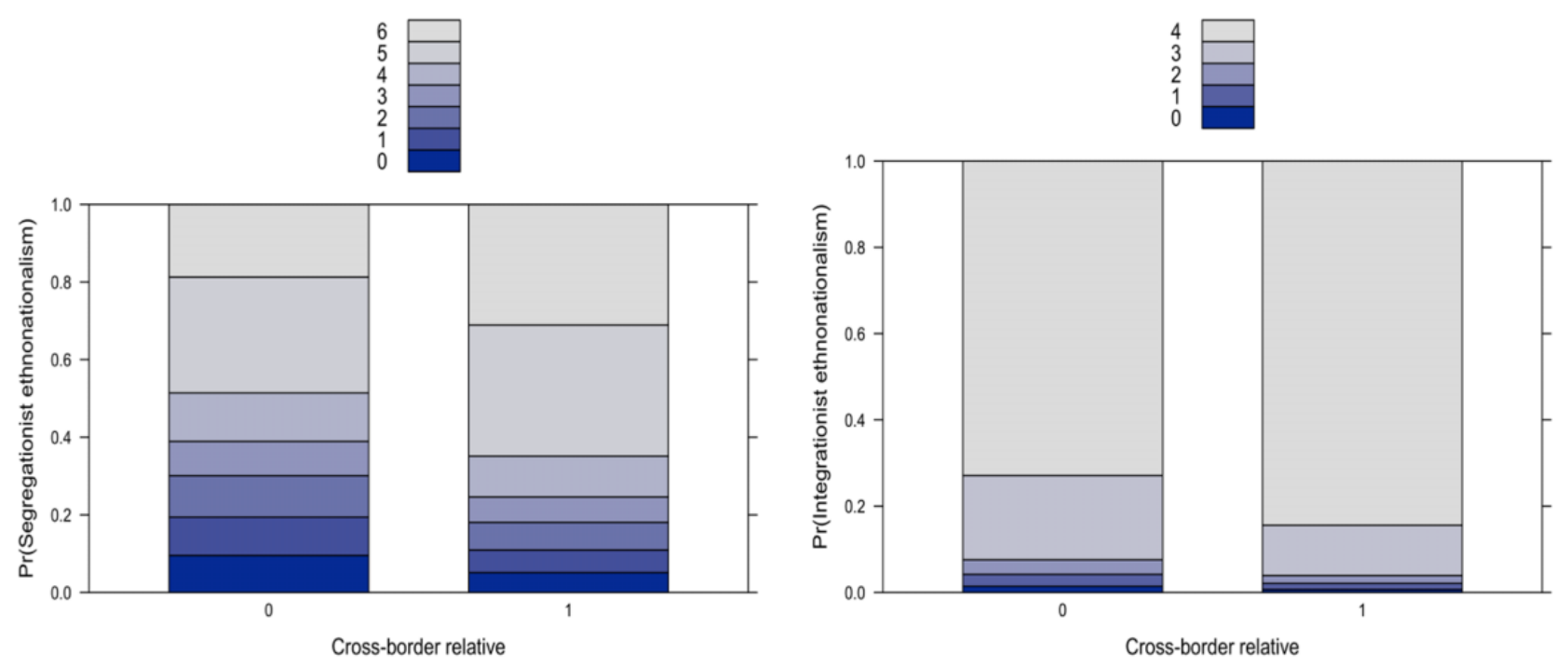

Figure 1. The cumulative predicted probabilities of segregationist and integrationist ethnonationalism

being in the highest category of integrationist ethnonationalism (Category 4) by $11.5 \%$.

Regarding the impact of having close relatives in European countries, the results indicate that, as anticipated, such transnational ties and networks do not generate the same impact. In other words, Turkish Kurds' links to Europe do not empower their ethnic demands, confirming the second hypothesis. Rather, links to Europe seem to suppress Turkish Kurds' ethnopolitical demands: ties to European Kurds have the opposite impact on segregationist ethnonationalism (Models $1 \mathrm{~b}$ and $1 \mathrm{~d}$ ) and no impact on integrationist ethnonationalism (Models $2 \mathrm{~b}$ and $2 \mathrm{~d}$ ). This is an interesting result because compared to Kurds in Turkey, Kurds in Europe have enjoyed relatively more cultural and political rights and freedoms. For instance, they have been allowed to speak, publish, and broadcast in Kurdish; learn the Kurdish language; organize social and cultural events such as Newroz (New Year) celebrations; and establish various pro-Kurdish associations, foundations, centers, and media (van Bruinessen, 1998, 2000; Eccarius-Kelly, 2002; Adamson, 2013). Thus, one might expect that Kurds in Turkey would learn from and be inspired by the concessions granted to the Kurdish diaspora in Europe and request similar rights from the Turkish state. This study's empirical findings, however, indicate that Kurds with strong transnational connections to the European Kurdish diaspora are not really more ethnonationalist than those who do not have such transnational connections or ties.

The differential impact of the variables Cross-border relative and European relative on Kurds' ethnonationalist tendencies and demands indicates that not all kinds of transnational ties or linkages and interactions promote individuals' ethnic awareness and mobilization. Familial ties to and interactions with nearby conflict countries and regions where ethnic-kin groups achieved major gains against the central state are more likely to empower ethnic consciousness and mobilization. This study suggests that conflict between a nearby state and ethnic kin increases the salience of ethnic consciousness, identities, and attachments, and that these dynamics and processes facilitate ethnic learning and inspiration. Thus, ethnic group members are more likely to learn from and be inspired by the achievements of ethnic-kin groups in nearby conflict countries. This finding implies that as we assess the influence of transnational ethnic ties and interactions on ethnic mobilization and conflict, we should take into account the larger strategic environment. As some of the existing studies also suggest, a particular strategic setting (e.g. a conflict setting) might be more favorable for ethnic learning and inspiration than another (e.g. a non-conflict setting) (see Walter, 2006; Forsberg, 2008).

The striking difference noted above further suggests that proximity to a conflict country with ethnic kin is an important factor in contagion processes. As Cederman, Girardin \& Gleditsch (2009: 410) claim, 'the crossborder ties most relevant for influencing the risk of civil wars are those pertaining to groups that are geographically close'. Similarly, Forsberg (2013: 333) emphasizes that 'proximity is an important element delimiting the relevant strategic environment of ethnic groups. Ethnic groups are thus considered more likely to respond to 
domino effects if the distance to the group being granted a concession is relatively small.'

\section{Conclusions and implications}

This study provides a micro-level analysis of the dynamics and processes of conflict contagion in the context of Turkey's Kurdish conflict, one of the longest civil conflicts in the post-World War II period. The statistical analyses indicate that compared to having relatives in non-contiguous and non-conflict countries (i.e. European countries), having relatives in neighboring countries that do host warring ethnic-kin groups increases ethnonationalist tendencies and claims against the center. In other words, familial ties to and interactions with other parts of their ethnic homeland, where ethnic-kin groups have achieved major economic, political, and territorial gains, boost Turkish Kurds' ethnonationalist orientations and demands, but the same does not apply to ties to and interactions with the Kurdish diaspora in a non-contiguous and non-conflict region (i.e. Europe). It is primarily due to transnational familial ties that amplify cross-border collaboration between transnational coethnics and the demonstration effect of mobilization and achievements by ethnic-kin groups in nearby conflict areas. Furthermore, strong transnational linkages to nearby countries that host conflicting ethnic-kin groups strengthen pan-ethnic identities, consciousness, feelings, and solidarities. In return, such pan-ethnic orientations and sentiments promote ethnic consciousness and mobilization. In brief, through various strategic and ideational mechanisms and processes, transnational familial ties to nearby conflict zones facilitate cross-border diffusion.

The findings of this study provide support for the broader claim that transborder linkages, factors, and processes, such as proximity to states experiencing ethnic conflict and transnational ethnic ties to groups in contiguous conflict countries, might exert a substantial impact on the likelihood of ethnic mobilization. Thus, the results suggest that, in addition to domestic processes, ethnonationalism might involve bordertransgressing processes, dynamics, and influences. This finding makes sense because social ties are not confined within national borders. Ethnic group members can and, as evidenced by this study, do - have strong tribal and familial ties and interactions across national borders, and these transborder connections appear to substantially shape their ethnonationalist awareness and orientations. As Forsberg (2013: 334) also notes, 'ethnic groups are outward-looking, hence [are] affected by events involving other ethnic groups, both within the same country and in the immediate surroundings'.

The Kurdish case further suggests that contagion dynamics and processes might vary substantially across the members of a particular ethnic group. Empirical analyses of contagion dynamics among Turkey's Kurds show that the effect of nearby ethnic mobilization and conflict on ethnonationalist orientations might be stronger among certain ethnic group members than others. In other words, some ethnic group members might be relatively more receptive to contagion processes than others. Therefore, in order to capture intragroup differences in terms of the contagion effect (i.e. the differential operation of contagion processes across the members of a particular ethnic group), it is necessary to broaden the conventional group-centric focus of the existing contagion literature and pay greater attention to individuallevel variables and factors. Until now, as far as can be determined, no study has directly tested the effect of transnational ties and interactions on ethnic awareness and mobilization at the individual level. As Cederman, Girardin \& Gleditsch (2009: 433) also advise, 'additional research is needed on the details of the bordertransgressing bond, especially as regards the nature of the actor-specific mechanism'. The current study's findings suggest that one way of getting a better grasp of the impact of border-crossing ties and bonds on ethnic mobilization is to disaggregate the analysis to an individual level. Thus, as a future study, collecting individuallevel data and conducting micro-level analyses in other conflict settings would be quite rewarding in terms of enhancing our theoretical and empirical knowledge of the dynamics and processes of conflict contagion.

\section{Replication data}

The dataset and do-files for the empirical analysis in this article, along with the Online appendix, can be found at https://www.prio.org/jpr/datasets/.

\section{Acknowledgements}

For useful comments and suggestions on earlier drafts of this study, I am grateful to Ekrem Karakoc, Jonathan J Ring, Efe Tokdemir, and the editors and three anonymous reviewers.

\section{Funding}

The data that this study utilizes derive from a survey research project funded by TEPAV (the Economic Policy Research Foundation of Turkey). 


\section{ORCID iD}

Zeki Sarigil (D) https://orcid.org/0000-0001-7188-004X

\section{References}

Adamson, Fiona B (2013) Mechanisms of diaspora mobilization and the transnationalization of civil war. In: Jeffrey $\mathrm{T}$ Checkel (ed.) Transnational Dynamics of Civil War. New York: Cambridge University Press, 63-88.

Ayres, R William \& Saideman Stephen (2000) Is separatism as contagious as the common cold or as cancer? Testing international and domestic explanations. Nationalism and Ethnic Politics 6(3): 91-113.

Bakke, Kristin M (2013) Copying and learning from outsiders? Assessing diffusion from transnational insurgents in the Chechen wars. In: Jeffrey $\mathrm{T}$ Checkel (ed.) Transnational Dynamics of Civil War. New York: Cambridge University Press, 31-62.

Baser, Bahar (2017) Intricacies of engaging diasporas in conflict resolution and transitional justice: The Kurdish diaspora and the peace process in Turkey. Civil Wars 19(4): 470-494.

Belge, Ceren (2016) Civilian victimization and the politics of information in the Kurdish conflict in Turkey. World Politics 68(2): 275-306.

Brubaker, Rogers (2009) Ethnicity, race, and nationalism. Annual Review of Sociology 35: 21-42.

Buchanan, Allen E (1991) Secession: The Morality of Political Divorce from Fort Sumter to Lithuania and Quebec. Boulder, CO: Westview.

Buhaug, Halvard \& Kristian Skrede Gleditsch (2008) Contagion or confusion? Why conflicts cluster in space. International Studies Quarterly 52(2): 215-233.

Cederman, Lars-Erik \& Kristian Skrede Gleditsch (2009) Introduction to special issue on 'disaggregating civil war'. Journal of Conflict Resolution 53(4): 487-495.

Cederman, Lars-Erik; Luc Girardin \& Kristian Skrede Gleditsch (2009) Ethnonationalist triads: Assessing the influence of kin groups on civil wars. World Politics 61(3): 403-437.

Cederman, Lars-Erik; Kristian Skrede Gleditsch \& Halvard Buhaug (2013) Inequality, Grievances, and Civil War. New York: Cambridge University Press.

Cederman, Lars-Erik; Kristian Skrede Gleditsch, Idean Salehyan \& Julian Wucherpfennig (2013) Transborder ethnic kin and civil war. International Organization 67(2): 389-410.

Cederman, Lars-Erik; Andreas Wimmer \& Brian Min (2010) Why do ethnic groups rebel? New data and analysis. World Politics 62(1): 87-119.

Checkel, Jeffrey T, ed. (2013) Transnational Dynamics of Civil War. New York: Cambridge University Press.

Davis, David R \& Will H Moore (1997) Ethnicity matters: Transnational ethnic alliances and foreign policy behavior. International Studies Quarterly 41(1): 171-184.
Eccarius-Kelly, Vera (2002) Political movements and leverage points: Kurdish activism in the European diaspora. Journal of Muslim Minority Affairs 22(1): 91-118.

Eriksen, Thomas Hylland (2010) Ethnicity and Nationalism: Anthropological Perspectives. New York: Pluto.

Forsberg, Erika (2008) Polarization and ethnic conflict in a widened strategic setting. Journal of Peace Research 45(2): 283-300.

Forsberg, Erika (2013) Do ethnic dominoes fall? Evaluating domino effects of granting territorial concessions to separatist groups. International Studies Quarterly 57(2): 329-340.

Forsberg, Erika (2014a) Diffusion in the study of civil wars: A cautionary tale. International Studies Review 16: 188-198.

Forsberg, Erika (2014b) Transnational transmitters: ethnic kinship ties and conflict contagion 1946-2009. International Interactions 40(2): 143-165.

Gleditsch, Kristian Skrede (2007) Transnational dimensions of civil war. Journal of Peace Research 44(3): 293-309.

Gleditsch, Kristian Skrede \& Sara MT Polo (2016) Ethnic inclusion, democracy, and terrorism. Public Choice 169(3-4): 207-229.

Gourlay, William (2017) Kurdayetî: Pan-Kurdish solidarity and cross-border links in times of war and trauma. Middle East Critique 27(1): 25-42.

Griffiths, Ryan D (2016) Age of Secession: The International and Domestic Determinants of State Birth. Cambridge: Cambridge University Press.

Gurr, Ted Robert (1970) Why Men Rebel. Princeton, NJ: Princeton University Press.

Gurr, Ted Robert (1994) Peoples against states: Ethnopolitical conflict and the changing world system. International Studies Quarterly 38(3): 347-377.

Gurses, Mehmet (2015) Transnational ethnic kin and civil war outcomes. Political Research Quarterly 68(1): 142-153.

Gurses, Mehmet \& Nicolas Rost (2017) Religion as a peacemaker? Peace duration after ethnic civil wars. Politics and Religion 10(2): 339-362.

Harff, Barbara \& Ted R Gurr (2018) Ethnic Conflict in World Politics. New York: Routledge.

Hegre, Havard \& Nicholas Sambanis (2006) A sensitivity analysis of the empirical literature on civil war onset. Journal of Conflict Resolution 50(4): 508-535.

Hill, Stuart \& Donald Rothchild (1986) The contagion of political conflict in Africa and the World. Journal of Conflict Resolution 30(4): 716-735.

Horowitz, Donald L (1985) Ethnic Groups in Conflict. Berkeley, CA: University of California Press.

Jenne, Erin K; Stephen M Saideman \& Will Lowe (2007) Separatism as a bargaining posture: The role of leverage in minority radicalization. Journal of Peace Research 44(5): 539-558.

Kathman, Jacob D (2010) Civil war contagion and neighboring interventions. International Studies Quarterly 54(4): 989-1012.

Kaya, Zeynep \& Matthew Whiting (2017) Sowing division: Kurds in the Syrian war. Middle East Policy 24(1): 79-91. 
Konaev, Margarita \& Kirstin JH Brathwaite (2017) Dangerous neighborhoods: State behavior and the spread of ethnic conflict. Conflict Management and Peace Science 36(5): 447-468.

Kuran, Timur (1998) Ethnic dissimilation and its international diffusion. In: David A Lake \& Donald Rothchild (eds) The International Spread of Ethnic Conflict. Princeton, NJ: Princeton University Press, 35-60.

Lake, David A \& Donald Rothchild, eds (1998) The International Spread of Ethnic Conflict: Fear, Diffusion, and Escalation. Princeton, NJ: Princeton University Press.

Lawson, Fred H (2016) Explaining the spread of ethnosectarian conflict: Syria's civil war and the resurgence of Kurdish militancy in Turkey. Nationalism and Ethnic Politics 22(4): 478-496.

Lecours, André (2000) Ethnonationalism in the West: A theoretical exploration. Nationalism and Ethnic Politics 6(1): 103-124.

Lowe, Robert (2014) The emergence of Western Kurdistan and the future of Syria. In: David Romano \& Mehmet Gurses (eds) Conflict, Democratization, and the Kurds in the Middle East. New York: Palgrave Macmillan, 225-246.

Marcus, Aliza (2007) Blood and Belief: The PKK and the Kurdish Fight for Independence. New York: New York University Press.

McDowall, David (2004) A Modern History of the Kurds. London: IB Tauris.

Metternich, Nils W; Shahryar Minhas \& Michael D Ward (2017) Firewall? Or wall on fire? A unified framework of conflict contagion and the role of ethnic exclusion. Journal of Conflict Resolution 61(6): 1151-1173.

Oktav, Ozden Zeynep; Emel Parlar Dal \& Ali Murat Kursun, eds (2018) Violent Non-State Actors and the Syrian Civil War: The ISIS and YPG Cases. New York: Springer.

Regan, Patrick M \& Daniel Norton (2005) Greed, grievance, and mobilization in civil wars. Journal of Conflict Resolution 49(3): 319-336.

Roeder, Philip G (2018) National Secession: Persuasion and Violence in Independence Campaigns. Ithaca, NY: Cornell University Press.

Romano, David (2006) The Kurdish Nationalist Movement: Opportunity, Mobilization and Identity. Cambridge: Cambridge University Press.

Romano, David \& Mehmet Gurses, eds (2014) Conflict, Democratization, and the Kurds in the Middle East: Turkey, Iran, Iraq, and Syria. New York: Palgrave Macmillan.

Rothschild, Joseph (1981) Ethnopolitics: A Conceptual Framework. New York: Columbia University Press.

Saideman, Stephen M (2002) Discrimination in international relations: Analyzing external support for ethnic groups. Journal of Peace Research 39(1): 27-50.

Saideman, Stephen M \& R William Ayres (2000) Determining the causes of irredentism: Logit analyses of minorities at risk, data from the 1980s and 1990s. Journal of Politics 62(4): 1126-1144.

Salehyan, Idean (2007) Transnational rebels: Neighboring states as sanctuary for rebel groups. World Politics 59(2): 217-242.

Salehyan, Idean (2009) Rebels without Borders: Transnational Insurgencies in World Politics. Ithaca, NY: Cornell University Press.

Salehyan, Idean \& Kristian Skrede Gleditsch (2006) Refugees and the spread of civil war. International Organization 60(2): 335-366.

Sarigil, Zeki \& Omer Fazlioglu (2014) Exploring the roots and dynamics of Kurdish ethno-nationalism in Turkey. Nations and Nationalism 20(3): 436-458.

Sarigil, Zeki \& Ekrem Karakoc (2016) Who supports secession? The determinants of secessionist attitudes among Turkey's Kurds. Nations and Nationalism 22(2): 325-346.

Starr, Harvey \& Benjamin A Most (1983) Contagion and border effects on contemporary African conflict. Comparative Political Studies 16(1): 92-117.

Toft, Monica Duffy (2003) The Geography of Ethnic Violence: Identity, Interests, and the Indivisibility of Territory. Princeton, NJ: Princeton University Press.

van Bruinessen, Martin (1998) Shifting national and ethnic identities: The Kurds in Turkey and the European diaspora. Journal of Muslim Minority Affairs 18(1): 39-52.

van Bruinessen, Martin (2000) Transnational Aspects of the Kurdish Question. Florence: Robert Schuman Centre for Advanced Studies, European University Institute.

Verwimp, Philip; Patricia Justino \& Tilman Brück (2009) The analysis of conflict: A micro-level perspective. Journal of Peace Research 46(3): 307-314.

Walter, Barbara F (2006) Information, uncertainty, and the decision to secede. International Organization 60(1): 105-135.

Weidmann, Nils B (2015) Communication networks and the transnational spread of ethnic conflict. Journal of Peace Research 52(3): 285-296.

Wolff, Stefan (2006) Ethnic Conflict: A Global Perspective. Oxford: Oxford University Press.

ZEKI SARIGIL, b. 1979, PhD in Political Science (University of Pittsburgh, 2007); Associate Professor, Department of Political Science, Bilkent University (2008- ); current research interests: ethnonationalism, ethnic conflict, informal institutions; publications have appeared in European Political Science Review, European Journal of International Relations, European Sociological Review, Nations and Nationalism, Ethnic and Racial Studies; book: Ethnic Boundaries in Turkish Politics: The Secular Kurdish Movement and Islam (New York University Press, 2018). 